\section{MEDICAL LIFE IN A FRENCH COLONY.}

\author{
By Alfred S. Gubb, M.D. Paris, M.R.C.S.
}

C'LOSE upon 20 year's experience of medical practice in Algiers suggests certain reflections which may not be found devoid of interest.

\section{Opportunities of Practice in Algiers.}

To begin with, it is a great privilege to practise in a city provided with a well-equipped university and a big general hospital ; one can acquire a knowledge of cases and conditions often absent in private work. During the winter the incursion of British and American sun-worshippers brings a practice of humdrum variety, including the sort of ailments one expects to find among well-to-do travellers who live too well and take too little exercise. But in the summer, when Mustapha Supérieur is empty of its foreign risitors - when indeed the last of the betterclass French families have betaken themselves to this or that watering-place in the Pyrenees or Tosges, to Aix-les-Bains or Vichy, Contrexóville or Ax-lesThermes-then one enjoys ample leisure, pleasant except for the occasionally pronounced heat; the practitioner can revel in hospital experience and play once again at being a first-year student-for here even firstyear students "walk the hospitals" and are invited, nay compelled, to familiarise themselves with the outward aspects of disease ; they even administer anæsthetics when no better-qualified anæsthetist is available. For medical education the practical French system has much to recommend it ; students have to give intravenous injections and perform lumbar puncture, an examination in anatomy means a practical examination in actual dissecting, and an examination in surgery postulates a real operation on the cadaver in lieu of tiresome written descriptions and vain gestures with a wooden spatula which prevail in university circles in Great Britain.

\section{Various Unusual Cases.}

Strolling through the hospital one day last summer I saw my first case of hydrophobia. 'The patient, who had just been admitted, had sustained a dog-bite involving the left little finger on August 2nd. He underwent the complete course of treatment at the local Pasteur Institute, and all had gone well until Sept. 4th, when he began to feel unwell and developed weakness, culminating in paralysis, of the Jeft arm, with profuse salivation, 'sub-delirium, and inability to swallow. He died on Sept. 8th, and a few minutes after he had expired came four other persons who had been bitten on the same day by the same dog to inquire how he was getting on. They were naturally greatly depressed by the news. I may add that rabies is rather common in Algeria and strict precautions are enjoined, if not enforced, in respect of the canine population of urban districts.

But that was not my only "find." $\Lambda$ patient who had been sent in with the diagnosis of embarras gastrique fébrile (a euphemism for typhoid) was also discovered to have enlarged lymphatic glands in the groin and elsewhere. Rapid examination of a blood smear at once revealed the presence of the coccobacillus. The patient was promptly transferred to the isolation hospital-where, I have heard it said, people die, never of the disease for which they are admitted, but invariably of some other complaint contracted in loco-but in this instance at any rate the man succumbed to bubonic plague, which was diagnosed.

The next morning $I$ assisted at the initial steps of a hæmoculture in a case suspected to be Malta fever hemoculture seems to be the only way to arrive at a trustworthy diagnosis, the agglutination test being very unreliable. I have had two cases among $\mathrm{my}$ private patients in which recovery followed series of injections with a vaccine prepared by the Pasteur Institute. I usually resort to hæmoculture in suspected typhoid, because it enables me to arrive at a firm conclusion some days earlier than the agglutination test.

Skin Diseases.

In the out-patient department I saw two cases of "elephantiase grecque," alias leprosy, both mild forms. These cases are treated by means of colloid chaulmoogra oil (collobiase) with apparently beneficial results. At the skin clinic one sees a lot of interesting cases, though it must be conceded that 80 per cent. at least of the applicants for advice are suffering. from what they call la gale bedouine-why "bedouine" I know not, since it differs in no essential respect from common or urban itch. As for the various forms of parasitic infection of the scalp : ordinary ringworm, favus, alopecia areata, and so on, their name is legion, especially among the natives, owing to their habit of wearing a dirty chechia ${ }^{1} 18$ out of the 24 hours, and to their general lack of personal cleanliness.

\section{Syphilis.}

Many cases of syphilis at all stages and in all forms are to be found, affording ample opportunity to the hunter of treponemes, the favourite method being Tribondeau's (nitrate of silver and tannin), which has the merit of ease and facility. An occasional Oriental sore (bouton de Biskra) relieves the monotonous succession of the gonococcus and Ducrey's bacillus (soft chancre). Bubos in connexion with soft chancreare invariably treated by puncture, expression, and the injection of iodoform vaseline (10 to 15 per cent.) with almost uniformly successful results; the cure is virtually immediate. It is interesting to note that the Wassermann reaction is now so well known, even to the natives, that they often come to ask for " the blood test" in diseases standing in no relationship to syphilis.

\section{Malaria.}

In the summer months the principal pathological entertainment is provided by cases of malaria. The kind varies according to the season, and period of the season. Early, the tierce bénigne predominates, but later on there is a majority of tierce maligne, with a sprinkling of fievre quarte. Cases of pernicious fever are a source of astonishment to the inexperienced practitioner in the course of his first summer in Algiers. He is apt to be called to a patient, of any age, who is obviously very ill, presenting, it may be, a moderate degree of fever and some headache, or he may be drowsy or actually comatose. Unsuspicious of malaria, he is at a loss to interpret the symptoms, and while he is trying to find some plausible explanation-possibly awaiting the result of a bacteriological examination of a blood-smear-his patient expires. After one or two such experiences, of course, the scales fall from his eves, and in future, during the summer months, he views every febrile case through malarial spectacles. When in doubt he employs quinine en masse without waiting for a scientific diagnosis. Should it turn out to be something other than malaria, two or three grammes of quinine will have done no harm, while in many instances it may be themeans of saving the case.

One soon acquires the knack of determining the particular variety of parasite at a glance, though for that matter the identification is possessed of merely scientific interest, having no bearing on treatment though it may have some on prognosis. Staining specimens calls for a little tour de main, and even in skilled hands is not always all that could be desired. Then, too, the search is apt to tax one's patience. Unfortunately, negative cases take up most time, and even so a negative result does not peremptorily rule malaria out of court. Just as in syphilitic or gouty subjects one must always bear in mind the possible. pathogenic influence of the diathsis in visceral affections supervening at a later dat so in subjects. with a history of malaria we have o consider the advisability of associating quinine with such other symptomatic treatment as may apfear appropriate. 
It takes some years to become accustomed to treatment of diseases other than malaria in malarial countries.

In years gone by practically all the cases of malaria that crowded the wards at the Civil Hospital came from outside, from the alluvial plain of the Mitidja or from the more distant south. This year, however, a very large number of cases originated in Algiers itself, an unwelcome circumstance which we attribute to the presence in the city of large numbers of infected soldiers back from the East.

\section{Tlbe Sertices.}

ROYAL ARMY MEDICAL COLLEGE.

Maj. and Bt. Lt.-Col. J. A. Anderson, R.A.M.C., to be Professor, vice Lt.-Col. and Bt. Col. P. S. Lelean, C.B., C.M.G., R.A.M.C.

Maj, C. Ryles, R.A.M.C., to be Assistant Professor, vice Maj. and Bt. Lt.-Col. J. A. Anderson, R.A.M.C.

Cant. R. F. Wilkinson, late R.A.M.C., to be A.D.C. to the Gov.-Gen. and C.-in-C. of the Union of S. Afr. and High Commissioner for $\mathrm{S}$. Afr.

\section{ROYAL ARMY MEDICAL CORPS.}

Maj. J. W. Houston to be temp. Lt.-Col. whilst empld. as Asst. Dir. of Pathology.

Maj. W. W. Browne to be temp. Lt.-Col. whilst empld. as Asst. Dir. of Hygiene.

Capt. J. T. Simson to be Maj., and to remain secd.

Temp. Lt. B. Fitz-J. Haythornthwaite to be temp. Capt.

Temp. Maj. W. L. Cowardin relinquishes his commn. and retains the rank of Maj.

Capt. J. S. Sloper retires receiving a gratuity.

ARMY DENTAL CORPS.

Lt. (temp. Capt.) C. V. Walker to be Capt. SPECIAL RESERVE OF OFFICERS.

Capt. E. S. B. Hamilton to be Maj. TERRITORIAT، ARMY.

The undermentioned vacate the appt. of Hon. Col. of the Divisions mentioned: Hon. Col. (Lt.-Gen., ret. pay) Sir A. Keogh, G.C.B., G.C.V.O. (2nd Lond. Divn.), Hon. Col. T. R. Glynn (W. Lancs. Divn.), Hon. Col. (Col. T.F. Res.) de B. Birch, C.B., V.D. (W. Rid. Divn.), Hon. Col Sir J. Williams, Bt., G.C.V.O. (Welsh Divn.), Hon. Col. Sir T. C. Allbutt, K.C.B., F.R.S. (E. Angl. Divn.)

The undermentioned to be Hon. Cols. : Hon. Maj.-Gen. Sir B. G. A. Moynihan, Knt., K.C.M.G., C.B., from T.A. Res. (W. Rid. Divn.), Hon. Maj.-Gen. Sir A. A. Bowlby, K.C.B., K.C.M.G., K.C.V.O. (S. Mid. Divn.), Col. J. A. Jones, V.D., K.H.S. (Welsh Divn.), Col. J. Griffiths, C.M.G., T.D. (from ist E. Genl. Hosp., E. Angl. Divn.), Col. J. V. W. Rutherford, V.D. (from T.A. Res., North'n Divn.), Lt.-Col. A. Thome, V.D. (2nd Lond. Divn.), It.-Col. F. J. Knowles, T.D. (W. Lancs. Divn.), Lt.-Col. Sir W. R. Smith, T.D. (from Sanitary Service, H. Counties Divn.).

Col. T. F. Maswell, C.I.E.. T.D. (Hon. Lt. in Army) having attained the age limit, is retired and retains the rank of Col., with permission to wear the prescribed uniform.

Officers relinquishing their commns. and retaining their rank except where otherwise stated : Lt.-Cols. H. C. Donald and J. R. Harper, with permission to wear the prescribed mniform. Majs. A. Innes and J. Walker. Capts. (Bt. Maj.) W. R. Bristow (granter the rank of Maj.), (Bt. Maj.) H. Sharpe, B. Hughes (granted the rank of Maj.). J. H. Crane (granted the rank of Maj.); H. Drummond (granted the rank ( Maj.), $A$. N. Worsley, R. E. T. Tatlow granted the rank Hamilton, G. H. H. Manfield (granted the rank of Maj.), A. C. Ainsley, H. Paterson (granted the rank of Maj.), J. A. Thomson, A. C. Haddow, L. W. Sparrow, J. F. Fdmiston (granted the rank of Maj.), G. Crawshaw, and F. C. Nichols. Majs. G. Potts, F. K. Smith, and M. H. Barton; Capts. F. Clayton (granted rank of Major), W. R. Collingridge, K. H Gill, C. B. Hawthorne, 1. H. Bell, L. E. Hughes, W. E. Fitzgerald, T. Higson, W. K. Churchhouse, T. S. Stafford, F. N. Threlfall, a ${ }^{m}$ Van Someren.

Surg.-Maj. R. I McQueen (Oity of London) relinquishes his commn. and $\mathrm{r}$ tains his rank with permission to wear the prescribed unifkrm.

Sanitary Service.--Maj. (Bt. I.t.-Col.) H. F. Horne relinquishes his commn, retains his rank, and is permitted to wear the prescribed aniform.
TERRITORIAL FORCE RESERVE.

Maj. E. Gray, having attained the age limit, is retired and retains the rank of Maj., with permission to wear the prescribed uniform.

Capts. W. Bain and I. D. Stubbs relinquish their commns., and retain the rank of Capt.

\section{ROYAL, AIR FORCE.}

T. I. P. Harries is granted a short service commission as a Flight Lt.

Flight Lt. W. G. Weston and Flying Officer T. A. G. Hudson are granted temporary commns. in the ranks stated.

Capt. H. H. Mallet, Army Dental Corps, is granted a temporary commission as a Flight It. while attached for duty with the R.A.F

INDIA AND THE INDIAN MEDICAI SERVICE.

Lt.-Col. R. A. Needham will be associated with Dr. Norman Walker in the inquiry into the question of midwifery training in medical colleges in India.-Dr. Norman Walker is visiting India on behalf of the General Medical Council.-Lt.-Col. I. J. M. Deas has been appointed to hold visiting medical charge of the Eastern Rajputana States Agency, in addition to his duties as Agency Surgeon, Kotah and Jhalawar.-Maj. L. H. L. Mackenzie will officiate as Agency Surgeon, Gilgit.-The services of Maj. J. C. G. Kunhardt have been temporarily placed at the disposal of the Burma Government-Maj. A. W. Harvey, Officer Commanding Marine Lines War Hospital, Bombay, has been appointed to be a Justice of the Peace within the limits of the town of Bombay.-Maj. E. S. Phipson, health officer, Simla, has been placed on special duty with the Government of India, to assist Maj. G. G. Jolly in connexion with the medical arrangements for the camps of H.R.H. the Prince of Wales.-Maj. (actg. Lt.-Col.) R. E. Flowerdew and Capt. (actg. Maj.: J. Rodger relinfuish their actg. rank on ceasing to be employed as Registrars of General Hospitais in India.

DEATHS IN THE SERVTCES.

Major-General W. H. B. Robinson, C.B., I.M.S., whose death on Feb. 7 th is announced from Calcutta, in his fiftyninth year, received his first commission in 1886 and sav service in the Burmese Expedition of 1885-1889 (mentioned in despatches, medal and two clasps), in the Waziristan Expedition 1894-1895 (clasp), and with the relief force in Chitral in 1895 (medal and clasp). He was also at Tirah in 1897-1898 and took part in the operations in the Bara Valley (two clasps). At intervals during his Indian service he was residency surgeon at Rajputana and at various central Indian States. In the recent war he was employed with the Indian Expeditionary Force in France (twice mentioned in despatches and awarded the C.B.). In 1919 he was appointer honorary sinrgeon to the King. Major-General Robinson's recent services also included those of Sanitary Commissioner of the Central Provinces, Surgeon-General in Bengal, and Acting Director-General of the Indian Medical Service.

Aberdeen Royal InfIRmary : ANNUAL Report, The annual report of the Aberdeen Royal Infirmary states that 3802 cases were treated during the year 1921. Of these 955 were medical and 2847 were surgical. In the outpatient department 15,246 cases were seen. The average number of beds in daily occupation was 219 , and the average length of stay in hospital was 25 days. There were 2370 operations performed on in-patients, 102 more than in the preceding year. The death-rate in cases treated was about 8.4 , but if 88 deaths which occurred within 48 hours of admission are deducted, the rate is reduced to about 6 per cent, as against 7 per cent. in 1920. Forty-seven discharged disabled soldiers were treated during the year. In all 398 discharged disabled soldiers have been treated in the infirmary. The financial position is distinctly better than it was in 1920 , though there is still a deficit of $\$ 741$ on the year's working. Last year the deficit was $£ 1672$. While the income from parish collections, donations, and patients' payments has decreased, that from church collections, employees' contributions, entertainments, and invested property income has increased. The average cost per occupied bed-based upon the total ordinary expenditure, less the cost of outpatients (reckoned at $2 s$. each)-was $£ 1245 s .2 d$., as compared with $£ 1263 s, 6 d$ last year, and the average cost of each inpatient was $£ 8$ 2s. $9 d$., as against $£ 817 \mathrm{~s}$. $5 d$. last year. Through the generosity of the Aberdeen University Court the infirmary has received an electrocardiograph, and a further addition to the equipment of the institution will be a quantity of radium to be lent by the Medical Research Council. A grant of $\mathfrak{L} 4620$ from H.R.H. the Prince of Wales's National Relief Fund has enabled the Board to carry out the renewal of the electrical lighting installation, and some interior painting. 